\title{
Assertiveness as the Predictor of Adjustment to University Life amongst University Students
}

\section{İzzet Parmaksiz}

Dr., Niğde Ömer Halisdemir University, Faculty of Education, Turkey, izparm44@gmail.com

The main purpose of this study was to examine whether or not assertiveness predicted adjustment to university by determining university students' adjustment levels to university. The study was conducted with first-year students who were attending a university in Central Anatolia in 2018. A total of 438 students, 322 females and 116 males, participated in the study. The data were collected using the University Life Scale, the Assertiveness Scale and the Personal Information Form developed by the researcher. For data analysis, t-test was employed for binary variables, and one-way ANOVA was employed for multiple variables. Whether or not students' assertiveness predicted adjustment to university was determined by regression analysis. The study findings revealed that students' sex, high school they graduated from, the number of their siblings, their source of income, social activity they engaged in prior to university and their accommodations did not have effect on their adjustment to university. However, choosing their major willingly, perceiving their income as sufficient, the city they lived in and perception of their economic situation had effects on their adjustment to university. Furthermore, the study determined that the university students' assertiveness total scores predicted their adjustment to university, emotional adjustment, personal adjustment, adjustment to the opposite sex, social adjustment, academic adjustment and total adjustment scores.

Keywords: assertiveness, adjustment, university life, adjustment to life, student

\section{INTRODUCTION}

Adjustment may be considered one of the most basic life skills. Every change in life also brings about adjustment process. Adjustment refers to the harmony of the individual with himself or herself and with the other elements around him or her (Brady-Amoon \& Fuertes, 2011). In psychology, adjustment is the individual's ability to cope with problems and new situations he or she encounters in routine life (Weiten, Dunn \& Hammer, 2012). Adjustment to both social and other environmental factors is essential to improve the quality of life. University life is considered a period where young people

Citation: Parmaksız, İ (2019). Assertiveness as the Predictor of Adjustment to University Life amongst University Students. International Journal of Instruction, 12(4), 131-148. https://doi.org/10.29333/iji.2019.1249a 
can have great experiences and achieve their dreams (Gökkaya, 2016). This period, between the ages of 18 and 25 after high school, is a period in which the individuals feel grown-up but are not yet fully competent (Mercan \& Y1ld1z, 2011). The young people who have to move away from their close environment and enter a different environment must adjust to this new environment as soon as possible (Karahan, Sardoğan, Özkalama \& Dicle, 2005). Adjustment levels of university students are affected due to situations caused by individual and environmental factors in this new and different environment (Sürücü \& Bacanlı, 2010; Memduhoğlu \& Tanhan, 2013). This adjustment process involves adjustment to university life, emotional adjustment regarding the individual's self-acceptance and assertiveness based on self-perception, social adjustment encompassing communication with friends, relationships with the opposite sex and academic adjustment (Aladağ, Kağnıcı, Tuna \& Tezer, 2003).

In general, the problems of these individuals starting university recently have periodic common characteristics. However, due to individual characteristics, different problem areas also manifest themselves. The variables causing different problems are the individual's age, sex, economic and cultural characteristics, personal attitudes, special skills, self-esteem (self-confidence) and social skills. Failure to resolve these adjustment problems may extend their adjustment to university, and this may even lead them to drop out of school (Mercan \& Y1ld1z, 2011). Since adjustment affects the decision to drop out of school and their academic performance, it is one of the most challenging issues for the first-year students (Crede \& Niehorster, 2012).

Students' expectations about university life are positive but these expectations are not generally proportional to concrete experiences. Students experience disappointment because their expectations and the real situations around them differ from each other (Baker, McNeil \& Siryk, 1985). This indicates that adjustment to university should be paid more attention to. A study conducted by Şimşek (2013) revealed that students who had just started university had a $45 \%$ tendency to drop out. The reasons behind this high rate were personal attitudes, close environment and school. University students' struggle to deal with these problems and not being able to meet their needs affect their quality of life and psychology (Ceyhan, 2011). Going to university is referred to as a turning point because going to university is the key to having a successful identity and a respected professional status (Mercan \& Y1ldı, 2011). Due to university's critical significance, the problems students encounter should be solved immediately so that these adjustment problems can also be reduced.

In order to facilitate the adjustment process, the negative conditions should be turned into positive ones. However, having the appropriate personality traits that will facilitate individuals' adjustment is also vital. The individuals' interaction with their environment and their adjustment effort, and all the characteristics making them different from others constitute their personality (Yavuzer, 2002). Positive personality characteristics also facilitate adjustment. Assertiveness, a significant skill, is one of these positive personality characteristics. Individuals with high level of assertiveness can personally, emotionally and socially adjust better (Alberti \& Emmons, 2002; Moon, 2009; VoltanAcar et al., 2008). The individuals need to have assertive characteristics in order to show their existence in society. Assertiveness involves individuals being useful to both 
themvselves and to the people they are in contact with (Voltan-Acar et al., 2008). Assertiveness is also defined as individuals' awareness of their rights and the rights of other people and their ability to reflect this awareness to daily life (Ateş, 2013). Assertiveness is at the mid-point between passiveness and aggressiveness (Voltan-Acar, 2004). It is also expressed as a social skill that can be learned and improved. Therefore, social environment and support from the social environment are vital to being assertive (Bishop, 2013). In this way, assertiveness enables individuals to follow a more active way to develop better social relationships and solve problems. Moreover, individuals who solve their problems more effectively need less psychological help (Akeren, 2017). In interpersonal communication, assertiveness refers to a communication in which each individual is equal. It also includes mutual worthiness and respect. Thus, individuals can act with a sense of mutual trust and sincerity (Güdek, 2014).

Existence of assertive individuals will help solve the problem of not being understood, which is one of the greatest barriers in communication. Overcoming these barriers minimizes social breaks and contributes to the elimination of negative consequences caused by conflicts (Hartley, 1999 cited in Uz-Baş, 2017). As a skill, assertiveness is a behavioral characteristic that improves the quality of social life because the communication skills of assertive people are more advanced than nonassertive people (Karahan, 2005). Effective communication also involves minimizing the problems encountered. The key to an individual being socially active is to have traits such as being able to express himself or herself, being self-confident, being accepted by others and being approved by others in social areas. These characteristics are qualities referring to adjustment skills. These qualities can be achieved by being assertive. In order for the individual to exist in the society, he or she must have assertive behavioral characteristics. Being socially skillful means being assertive at the same time. Individuals with social skills are expected to have high social adjustment levels, and there is a significant relationship between social skills and school adjustment (Kabasakal $\&$ Çelik, 2010). Assertiveness is of great importance during university years. In this period, students try to adjust to their environment. They try to understand the differences between passive, aggressive and assertive behaviors, and experience their effects on their lives (Gündoğdu, 2012). In addition, starting university brings about trust in individuals and forces them to take on responsibilities. Many factors such as being a candidate for an occupation, increase in situations where independent decisions have to be made, and adjustment to different environment and people after coming from different culture and standards of living are closely related to being assertive (Y1lmaz \& Ekinci, 2001). A study conducted by Karahan, Sardoğan, Özkalama and Dicle (2005) on assertiveness as a social skill revealed that students with a high level of assertiveness had higher levels of university adjustment compared to students with low level of assertiveness. Assertiveness has positive correlation with social adjustment (Simarmata \& Rahayu, 2018). Rini, Bahri and Zuliani (2016) determined a significant relationship between assertive behavior and social adjustment. Assertiveness was a significant predictor of adaptation to the university environment, academic adjustment, social adjustment, personal adjustment, and emotional adjustment, which are all subdimensions of university life adjustment. The studies on adjustment to university life 
have not examined this subject using many variables. However, the subject was examined using the reliability variable (Amanvermez, 2015). Various studies conducted with university students determined that high level of assertiveness is associated with adjustment (Richardson, 2000). Individuals with assertive characteristics communicate more effectively with their environment and are adjusted to their environment. On the other hand, those who are not assertive are highly resistant to change (Morganett, 2005), and fail to adjust because assertive behavior is a characteristics affecting both the satisfaction of the individuals with their life and quality of their relationships with others (Pamuk, 2013). For this reason, assertiveness, which facilitates students' adjustment to school and has a positive effect on their self-esteem (Köseler, 2006), is very important and needs to be emphasized.

The Role of Universities in Providing Services to New Students. The universities can encourage students' participation by giving priority to the promotion of socio-cultural activities in universities. The universities can also provide economic resources such as scholarships and credits to students who need them. In addition, they can ensure free participation of students in social and cultural activities. Part-time work opportunities can be provided for students who want to work part-time in the university or outside the university. Guidance and psychological counseling services can be provided for students in order to reduce their adaptation problems (Özkan \& Y1lmaz, 2010). Personality services for students can be developed (Kacur \& Atak, 2011). It is believed that universities can prepare multifaceted orientation programs for new students. (AkhunlarTurgut, et. al, 2018).

\section{Purpose}

Literature on adjustment to university life shows that there are only very few studies that consider assertiveness as a predictive variable. In parallel with the technological and social changes, this study came to existence taking into consideration that studies on adjustment to university life should be updated with different sample groups. In this respect, the purpose of this study was to examine the contribution of the assertiveness variable on predicting university students' levels of general adjustment to university life, adjustment to university environment, emotional adjustment, personal adjustment, adjustment to the opposite sex, academic adjustment and social adjustment.

\section{METHOD}

This study is a relational study aiming to examine the relationships between university students' general adjustment to university life and their assertiveness levels.

\section{Study Group}

The study group consisted of 438 first-year students who were studying at the Faculty of Education at a university in Central Anatolia during the Spring semester of the 20172018 academic year. 88 of the participating first-year students were majoring in Mathematics Education (20.09\%), 92 in Turkish Education (21\%), 58 in Science Education (13.24\%), 108 in Elementary Education (24.65\%), and 92 in Psychological Counseling and Guidance $(21 \%)$. The participants were selected from the Faculty of Education because teacher candidates emotionally and socially express themselves 
better. Also, first-year students were specifically selected since university students' adjustment problems are observed more during their first year (İkiz et al., 2015). These randomly selected students volunteered to participate in the study. 322 of the participating students were female $(73.51 \%)$, and 116 were male $(26.49 \%)$. Their ages ranged between 18 and $22(\mathrm{M} \pm \mathrm{SD}=19.42 \pm 2.50)$.

\section{Data Collection Tools}

Voltan-Acar Assertiveness Inventory: The Voltan-Acar Assertiveness Inventory was developed by Voltan-Acar and Öğretmen (2007). The inventory measures the assertiveness of university students. There are 17 items for passiveness and 11 for assertiveness in the inventory. The inventory consists of a total of 28 items. It is a sixpoint Likert type measurement tool. The score obtained from this measurement tool ranges between 28 and 168. The high score obtained from the inventory indicates high assertiveness level. The internal consistency coefficient of the inventory was 0.83 for the passiveness dimension, 0.78 for the assertiveness dimension, and 0.87 for the total inventory. Conducting the study with a sample of 35 people for the test-retest technique while developing this measurement tool was reported as one of the inventory's limitations. For this reason, reexamining the reliability of the test-retest technique by administering the inventory to a larger sample was recommended. Therefore, at a later date, reliability of the inventory was reexamined by using the test-retest technique with a new sample consisting of 113 people. According to the results of this analysis, test-retest reliability was 0.78 , a value close to the previous results. This measurement tool showed that aggressiveness and assertiveness were two different concepts. Developed to determine assertiveness levels of individuals, this inventory was found to be a valid and reliable measurement tool (Voltan-Acar \& Öğretmen, 2007). In the present study, the internal consistency coefficient of the inventory was calculated using Cronbach's Alpha method and found to be 0.83 .

University Life Scale: University Life Scale (ULS) was developed by Aladağ, Kağnıcı, Tuna and Tezer (2003) to determine the university adjustment levels of students who recently started university. Developed as a seven-point Likert-type measurement tool, the scale consists of 48 items ranging from "not at all applicable" (1) to "totally applicable" (7). The items 1, 2, 4, 5, 6, 7, 8, 10, 11, 13, 16, 17, 19, 21, 22, 24, 25, 27, $29,31,32,33,35,38,40,42,44,46$ and 47 are reverse items. High score obtained from the scale indicates adjustment, whereas low score indicates maladjustment. The scale consists of six sub-dimensions, namely, adjustment to college environment, emotional adjustment, personal adjustment, relationships with the opposite sex, academic adjustment, and social adjustment. The correlations between the sub-dimensions ranged from 0.33 to 0.48 , and the correlations between the sub-dimensions and the total score ranged from 0.64 to 0.77 . The Cronbach Alpha coefficients of the sub-dimensions were 0.80 for the adjustment to university environment, 0.79 for emotional adjustment, 0.76 for personal adjustment, 0.73 for the relationships with the opposite sex, 0.70 for academic adjustment, and 0.63 for social adjustment. The internal consistency coefficients of the sub-dimensions were between 0.63 and 0.80 . The internal consistency coefficient for the total scale was 0.91 (Aladağ, Kağnıcı, Tuna \& Tezer, 2003). In this present study, the internal consistency coefficients were 0.72 for the adjustment to 
university environment, 0.75 for emotional adjustment, 0.73 for personal adjustment, 0.46 for the relationships with the opposite sex, 0.67 for academic adjustment, and 0.65 for social adjustment. The internal consistency coefficient for the total scale was 0.88 .

Personal Information Form: Developed by the researcher, the form contains the independent variables of the study such as students' age, sex, number of siblings, rank of placement and accommodation, the high school they graduated from, the place they have lived the longest, the economic status of their family, from where their monthly income comes from, whether or not they find their income sufficient and whether or not they are engaged in social activities before coming to university.

\section{Procedure}

After obtaining the official approval and research ethics committee approval from the university to conduct the study, Voltan-Acar Assertiveness Scale (Voltan-Acar \& Öğretmen, 2007), University Life Scale (Aladağ, Kağnıc1, Tuna \& Tezer, 2003) and Personal Information Form were administered to university students in the spring semester of 2018 by the researcher. Before the administration of the measurement tools, the purpose of the study was explained to the students. The students were provided with an environment where they could fill out the tools comfortably, and sufficient time was given to the students. After the researcher provided the instructions on the tools, they were filled out under the supervision of the researcher. Administrations took approximately 20 minutes.

\section{Data Analysis}

In this study, the relationship between the dependent variable and the independent variable was examined and homogeneity of variance (normal distribution) was examined as the first step. Levene test was performed for the homogeneity of the groups. Levene test results sig (p) value was examined. A greater than 0.05 value indicates that there is no difference (Akdağ, 2011). Levene test results ranged from 0.12 to 0.95 for all the variables. Kolmogorov-Smirnov test was also used for normal distribution. According to Kolmogorov Smirnov test, $p$ value was not significant ( $p>0.05$ ) (Orhunbilge, 2000). The fact that the result was not significant indicates that the distribution was normal. The skewness value was between 0.24 and 1.49 for all variables, and the kurtosis value was between -0.15 and 1.19 for all variables. The fact that the skewness and kurtosis coefficients were close to \pm 1 limits can be interpreted as scores not showing excessive deviation from the normal (Büyüköztürk, Çokluk \& Köklü, 2010). Huck (2008) states that the skewness values should be between +1 and -1 , and the kurtosis values between +2 and -1 . According to the results of this statistical analysis, sample group of the study had a normal distribution. T-test was employed for binary comparisons (sex, willingly choosing their major, finding the income sufficient, accommodation), and one-way variance analysis was employed for multiple comparisons (major, the high school they graduated from, rank of placement, number of siblings, the place they live, economic status, income source and accommodation place). Hierarchical regression analysis technique was employed when examining whether or not assertiveness predicted students' adjustment to university life. Data were analyzed in terms of outliers. The 
calculation of the outliers that had Mahalanobis distance value were done, and it was determined that there were no data with outliers. It is stated that there isn't a multicollinearity problem when Variance Inflation Factor (VIF) have a value below 10 or Tolerance Value (TD) have a value above 0.10 (Akgül \& Çevik, 2003; Çokluk et al., 2010). The medium level binary correlations between the independent variables indicated that there was no multicollinearity between variables. Also, the tolerance and VIF values were within acceptable limits. If the Durbin-Watson value is around 2, it means that there isn't an autocorrelation (Kalayc1, 2005). Durbin-Watson coefficient was used to test the autocorrelation. Durbin-Watson values were between 1.72 and 1.96. The data were analyzed in SPSS 22 program.

\section{FINDINGS}

\section{Preliminary Analysis}

It was determined that the difference between the university students' University Life Scale total score means was not significant according to the variables of sex $(\mathrm{t}(2-436)=-$ $1.40, \mathrm{p}>0.05)$ and social activity $(\mathrm{t}(2-436)=1.66, \mathrm{p}>0.05)$. On the other hand, the difference between means was significant according to the variables of choosing their major willingly $(\mathrm{t}(2-436)=2.05, \mathrm{p}<0.05)$ and their income perception $(\mathrm{t}(2-436)=3.07$, $\mathrm{p}<0.05$ ) (Table 1). According to this finding, adjustment to university life scores of students who chose their major willingly and stated to have sufficient income were higher than others.

Table 1

T-Test Results of University Students' University Life Scale Score Means According to Various Variables

\begin{tabular}{lllllll}
\hline Variables & & $\mathrm{N}$ & $\overline{\mathrm{X}}$ & $\mathrm{ss}$ & $\mathrm{t}$ & $\mathrm{P}$ \\
\hline \multirow{2}{*}{ Sex } & Female & 322 & 233.01 & 33.98 & \multirow{2}{*}{1.40} & \multirow{2}{*}{0.220} \\
Choosing the Major & Male & 116 & 241.05 & 45.08 & & \\
Willingly & Yes & 308 & 238.22 & 34.87 & 2.05 & 0.041 \\
Is the Income & Yes & 130 & 227.00 & 41,35 & & \\
Sufficient? & No & 254 & 244.07 & 3.07 & 3.07 & 0.002 \\
Social Activity & Yes & 140 & 228.67 & 3.07 & & \\
& No & 298 & 232.28 & 36.06 & \multirow{2}{*}{1.66} & 0.098 \\
\hline
\end{tabular}

The study findings showed that the difference between the university students' University Life Scale total score means was not significant according to the variables of major $\left(\mathrm{F}_{(5-433)}=0.64, \mathrm{p}>0.05\right)$, high school $\left(\mathrm{F}_{(4-434)}=0.12, \mathrm{p}>0.05\right)$, rank of placement $\left(\mathrm{F}_{(4-434)}=0.49, \mathrm{p}>0.05\right)$, number of siblings $\left(\mathrm{F}_{(4-434)}=0.11, \mathrm{p}>0.05\right)$, the income source $\left(\mathrm{F}_{(3-435)}=0.55, \mathrm{p}>0.05\right)$ and accommodation $\left(\mathrm{F}_{(5-433)}=1.41, \mathrm{p}>0.05\right)$. On the other hand, the difference between means was significant according to the variables of the place the students live in $\left(\mathrm{F}_{(4-434)}=4.10, \mathrm{p}<0.05\right)$ and the family's income $\left(\mathrm{F}_{(4-435}=4.81, \mathrm{p}<0.05\right)$ (Table 2). According to this finding, adjustment to university life scores of students who live in medium-sized cities and whose family income level was high were higher than others. 
Table 2

One-Way Variance Analysis (ANOVA) Results of University Students' University Life Scale Score Means According to Various Variables

\begin{tabular}{|c|c|c|c|c|c|c|}
\hline & & $\mathrm{N}$ & $\overline{\mathrm{X}}$ & Ss & $\bar{F}$ & $\bar{P}$ \\
\hline \multirow{5}{*}{ Major } & Math Education & 88 & 231.11 & 36.52 & \multirow{5}{*}{0.64} & \multirow{5}{*}{0.633} \\
\hline & Turkish Education & 92 & 241.76 & 34.61 & & \\
\hline & Science Education & 58 & 233.82 & 33.25 & & \\
\hline & Elementary Education & 108 & 231.74 & 38.03 & & \\
\hline & $\begin{array}{l}\text { Psychological Counseling } \\
\text { and Guidance }\end{array}$ & 92 & 237.21 & 42.41 & & \\
\hline \multirow{4}{*}{ Type of High School } & Science & 14 & 228.57 & 63.31 & \multirow{4}{*}{0.12} & \multirow{4}{*}{0.947} \\
\hline & Anatolian & 274 & 236.08 & 36.58 & & \\
\hline & Vocational & 56 & 234.07 & 32.18 & & \\
\hline & Other & 94 & 234.02 & 38.69 & & \\
\hline \multirow{4}{*}{ Rank of Placement } & $1-5$ & 272 & 232.74 & 38.61 & \multirow{4}{*}{0.49} & \multirow{4}{*}{0.685} \\
\hline & $6-10$ & 82 & 238.68 & 36.40 & & \\
\hline & $11-20$ & 68 & 239.50 & 32.45 & & \\
\hline & 21 and over & 16 & 239.37 & 42.00 & & \\
\hline \multirow{4}{*}{ Number of Siblings } & Only Child & 18 & 239.66 & 34.67 & \multirow{4}{*}{0.11} & \multirow{4}{*}{0.953} \\
\hline & 2 Siblings & 92 & 235.06 & 33.50 & & \\
\hline & 3-5 Siblings & 292 & 234.45 & 38.00 & & \\
\hline & 6 and over & 36 & 238.66 & 44.36 & & \\
\hline \multirow{3}{*}{ Income Source } & Scholarship & 194 & 232.20 & 35.59 & \multirow{3}{*}{0.55} & \multirow{3}{*}{.575} \\
\hline & Family & 228 & 237.64 & 38.98 & & \\
\hline & Working & 16 & 235.12 & 34.95 & & \\
\hline \multirow{5}{*}{ Accommodation } & State Dorm & 294 & 231.22 & 37.12 & \multirow{5}{*}{1.41} & \multirow{5}{*}{0.230} \\
\hline & Private Dorm & 20 & 237.30 & 34.43 & & \\
\hline & Family & 94 & 245.74 & 37.84 & & \\
\hline & Friends & 18 & 237.88 & 41.94 & & \\
\hline & Other & 12 & 240.50 & 27.29 & & \\
\hline \multirow{4}{*}{ The Place Lived } & Metropolis & 144 & 241.63 & 37.37 & \multirow{4}{*}{4.10} & \multirow{4}{*}{.007} \\
\hline & Medium-sized City & 116 & 242.25 & 32.85 & & \\
\hline & District & 88 & 220.75 & 38.75 & & \\
\hline & Village-Torn & 90 & 229.66 & 37.45 & & \\
\hline \multirow{3}{*}{ Family Income Level } & High & 62 & 242.41 & 27.07 & \multirow{3}{*}{4.81} & \multirow{3}{*}{0.009} \\
\hline & Medium & 352 & 235.94 & 37.87 & & \\
\hline & Low & 24 & 204.58 & 39.77 & & \\
\hline
\end{tabular}

\section{Correlations amongst variables}

Table 3 presents the correlation coefficients between the university students' general adjustment to university life scale and its sub-dimensions and their assertiveness. The table also presents the mean value and standard deviation values of the variables. 
Table 3

Correlation Coefficients between Assertiveness, University Life Scale and University Life Scale Sub-Dimensions

\begin{tabular}{|c|c|c|c|c|c|c|c|c|c|}
\hline Variables & Mean $\pm \mathrm{Sd}$ & $\mathrm{A}$ & TA & AUE & EA & $\mathrm{PA}$ & ROS & $\overline{\mathrm{AA}}$ & $\mathrm{SA}$ \\
\hline $\bar{A}$ & $133,55 \pm 18,79$ & 1.00 & & & & & & & \\
\hline TA & $235,14 \pm 37,30$ & $0.65 *$ & 1.00 & & & & & & \\
\hline AUE & $54,24 \pm 11,50$ & $0.37 *$ & $0.76^{*}$ & 1.00 & & & & & \\
\hline EA & $42,23 \pm 10,15$ & $0.64 *$ & $0.76^{*}$ & $0.45^{*}$ & 1.00 & & & & \\
\hline PA & $38,10 \pm 7,18$ & $0.43^{*}$ & $0.64 *$ & $0.39 *$ & $0.35 *$ & 1.00 & & & \\
\hline ROS & $34,10 \pm 8,74$ & $0.42 *$ & $0.65^{*}$ & $0.27 *$ & $0.39 *$ & $0.36^{*}$ & 1.00 & & \\
\hline $\mathrm{AA}$ & $33,30 \pm 7,95$ & $0.48^{*}$ & $0.71 *$ & $0.48^{*}$ & $0.53 *$ & $0.26^{*}$ & $0.37 *$ & 1.00 & \\
\hline SA & $33,15 \pm 6,45$ & $0.44 *$ & $0.73 *$ & $0.51 *$ & $0.44 *$ & $0.52 *$ & $0.41^{*}$ & $0.39 *$ & 1.00 \\
\hline
\end{tabular}

A: Assertiveness, TA: Total Adjustment, AUE: Adjustment to University Environment, EA: Emotional Adjustment, PA: Personal Adjustment, ROS: Relationships with the Opposite Sex, AA: Academic Adjustment, SA: Social Adjustment

Table 3 shows that there was a positive significant relationship between assertiveness total score and university life total score $(\mathrm{r}=0.65)$, AUE $(\mathrm{r}=0.37)$, EA $(\mathrm{r}=0.64)$, PA $(\mathrm{r}=0.43)$, ROS $(\mathrm{r}=0.42)$, AA $(\mathrm{r}=0.48)$ and SA $(\mathrm{r}=0.44)$ sub-dimensions.

\section{Regression Analysis Results}

Whether or not assertiveness predicted university students' adjustment to university life was examined by hierarchical regression analysis. Since students' university life scores differed according to the variables of willingly choosing their major, income level and income perception and the place the students live, these variables were first identified as "dummy" variables and later included in the regression analysis. Analysis results are presented in Table 3.

Table 4

Hierarchical Regression Analysis Results Regarding the Assertiveness Score's Prediction of University Life Total Score and University Life Sub-Dimension Scores

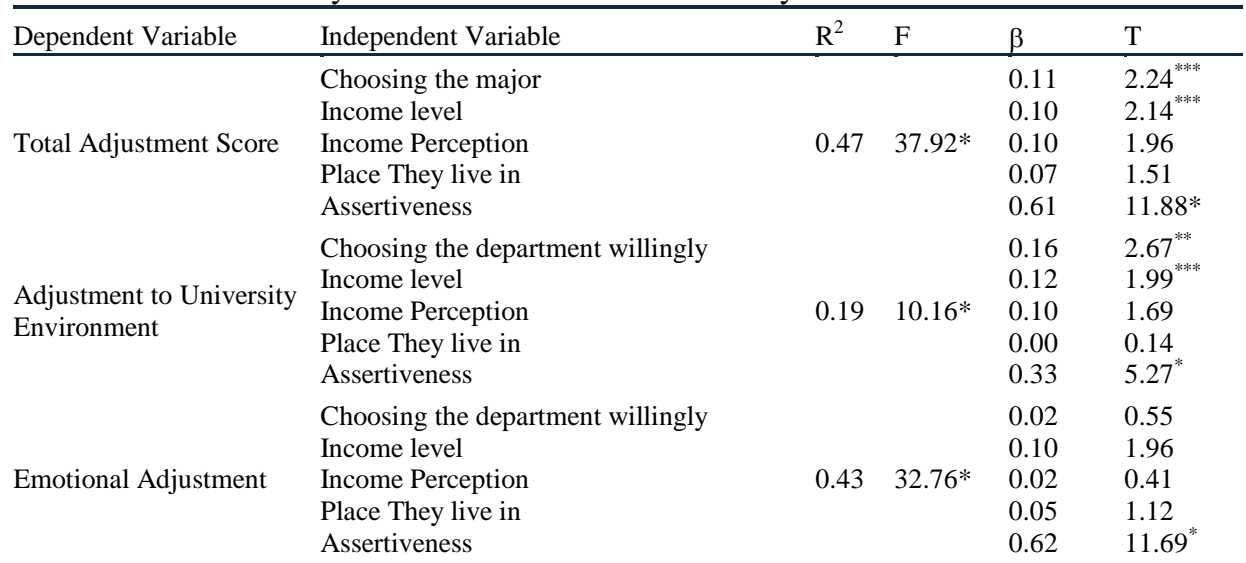




\begin{tabular}{lllrll} 
& Choosing the department willingly & & & 0.07 & 1.15 \\
& Income level & & & 0.01 & 0.16 \\
Personal Adjustment & Income Perception & 0.20 & $10.99^{*}$ & 0.04 & 0.76 \\
& Place They live in & & & 0.06 & 1.10 \\
& Assertiveness & & & 0.41 & $6.62^{*}$ \\
& Choosing the department willingly & & & 0.04 & 0.73 \\
Adjustment to Opposite & Income level & & & 0.02 & 0.32 \\
Sex & Income Perception & 0.19 & $10.04^{*}$ & 0.06 & 0.97 \\
& Place They live in & & & 0.03 & 0.52 \\
& Assertiveness & & & 0.41 & $6.45^{*}$ \\
& Choosing the department willingly & & & 0.03 & 0.54 \\
Academic Adjustment & Income level & & & 0.11 & 1.92 \\
& Income Perception & & $17.27^{*}$ & 0.14 & $2.45^{* * * *}$ \\
& Place They live in & & & 0.13 & $2.27^{* * *}$ \\
& Assertiveness & & & 0.42 & $7.09^{*}$ \\
& Choosing the department willingly & & & 0.13 & $2.12^{* * * *}$ \\
& Income level & & & 0.06 & 1.08 \\
Social Adjustment & Income Perception & 0.22 & $12.04^{*}$ & 0.04 & 0.66 \\
& Place They live in & & & 0.05 & 0.81 \\
& Assertiveness & & & 0.41 & $6.65^{*}$ \\
\hline
\end{tabular}

$* \mathrm{p}<0.001, * * \mathrm{p}<0.01, * * * \mathrm{p}<0.05$

The Regression Line Equation Is as follows:

Total Adjustment Score $=183,53+$ Assertiveness $1,21+($ Dummy Variables 9,126 + 17,827 + 7,588 + $7,151)$

Adjustment to University Environment $=40,85+$ Assertiveness, $205+$ (Dummy Variables 4,146 + 6,298 + $2,484+, 256)$

Emotional Adjustment $=30,67+$ Assertiveness, $335+($ Dummy Variables $, 639+4,592+, 445+1,497)$

Personal Adjustment $=33,19+$ Assertiveness, $159+($ Dummy Variables $1,105+, 317+, 698+1,225)$

Academic Adjustment $=23,188+$ Assertiveness, $179+($ Dummy Variables $, 547+3,962+2,342+2,658)$

Adjustment to Opposite Sex $=28,67+$ Assertiveness, $191+($ Dummy Variables $, 871+, 772+1,085+, 713)$

Social Adjustment $=26,94+$ Assertiveness, $142+($ Dummy Variables $1,818+1,887+, 534+, 803)$

Predictor of the level of adjustment to university, the variable of assertiveness was included in the analysis. After including the variables of willingly choosing the major, income level and income perception and place the students live, hierarchical regression analysis was performed. The analysis results revealed that the independent variables together explained $47.1 \%$ of the university life score, $19.3 \%$ of the adjustment to university environment score, $43.5 \%$ of the emotional adjustment score, $20.5 \%$ of the personal adjustment score, $19.1 \%$ of the adjustment to the opposite sex score, $28.8 \%$ of the academic adjustment score and $22 \%$ of the social adjustment score. These results indicated that assertiveness was a significant predictor of university life scale and its sub-dimensions. In addition, the other variables affecting adjustment increased the predictive power of assertiveness.

\section{DISCUSSION AND CONCLUSION}

According to the study findings, students' sex, high school they graduated from, the number of their siblings, their source of income, social activity they were engaged in prior to university and their accommodations did not have effect on their adjustment to university, whereas choosing their major willingly, perceiving their income as sufficient, the city they lived in and their perception of their own economic situation had effects on 
students' adjustment to university. Since the variable of number of siblings was a variable affecting perceived social support (Y1lmaz, Y1lmaz \& Karaca, 2008), the variable should have affected the adjustment process. However, the according to study results, there was no relationship between the aforementioned variable and adjustment level. Individuals who participated in social activities before university are expected to be social individuals. Büküşoğlu and Bayturan (2005) determined that the psychosocial development of young people participating in social activities was positively affected. However, this variable did not lead to a significant difference on the university life total score. This can be associated with the fact that adjustment to university life is a multifaceted process and that participating in pre-university social activities is not an important variable affecting this new process.

The present study also revealed that sex did not have an effect on adjustment. In parallel with this finding, the studies conducted by Mercan and Yildiz (2011) and Ceyhan (2011) also determined that sex was not associated with adjustment to university life. On the other hand, Öztemel (2010) and Bülbül and Acar-Güvendir (2014) stated otherwise. Their studies showed that the level of adjustment to university life differed according to sex.

In addition, this study put forth that the type of high school students graduated from did not affect adjustment to university to life. Similarly, Erdoğan et al. (2005) found that the type of high school did not differentiate the adjustment levels of university students. However, unlike the results of this study, Bülbül and Acar-Güvendir (2014) determined that the type of high school students graduated from affected their adjustment to university life.

The study also found that perception of economic status led to a significant difference on adjustment level. In their studies, Aladağ-Bayrak and Bülbül (2012), Mercan and Yildız (2011) and Erdoğan et al. stated that income level had an effect on students' adjustment to university life. As the students' level of income increases, their level of adjustment also increases. In addition, according to the results of this study, individuals who perceived their income as sufficient were more adjusted. From this point of view, individuals who do not find their income sufficient will have more difficulty in adjustment even though their income status is better than others. In addition, the income source was not found to be statistically significant regarding adjustment. In fact, whether the individuals found their income as sufficient had an effect on individuals' adjustment levels.

Furthermore, the study revealed that adjustment levels of students who live with their parents are higher but no statistically significant difference was found. The place of accommodation does not have a significant effect on students' adjustment (Rahat, 2014). Similarly, Öztemel (2010) determined that whether students lived in dormitories or student houses or stayed with their families did not have a significant effect on their adjustment levels. Baker and Schultz (1992), on the other hand, found that students living with their parents had fewer problems. Sevinç (2010) put forth that students who received support from their families were more adjusted. 
The study also determined that students who willingly chose their majors were more adjusted. Mercan and Yildiz (2011) found that the students who were placed to their first choices were more adjusted. Unlike these results, Özkan and Yilmaz (2010) found that the students who chose their major unwillingly had difficulty in adjusting to their university lives. Individuals who are studying at departments they want can cope more easily with adjustment since their readiness levels are higher.

The places where the individuals lived the longest affect their ability to adjust. The results of the present study revealed that if the students lived in bigger cities before coming to university, the place they lived before had a significant effect on adjustment to university life. Mercan and Yildiz (2011) found that the places students lived significantly differentiated their adjustment to university environment and their academic adjustment. Parallel to this result, Aktaş (1997) determined that young people who had been living in small places such as villages or towns had more difficulty in adjustment than others. University life, which brings with itself many changes, is also a critical period in terms of development. It is normal for young people to have adjustment problems during this period which is also an important starting point for social status and career goals. It is important for the university to take necessary preventative measures in order for them to overcome this process.

The regression analysis performed to predict the participants' adjustment levels to university showed that assertiveness was a significant predictor of the university life total score and all of the scale's sub-dimensions. Adjustment to university environment refers to the students feeling as part of their university, developing a loyalty to their university, finding the university's values and their own values similar and recognizing the support units at the university and taking advantage of them (Amanvermez, 2015). Bishop (2013) considers assertiveness as a personality trait and also as a social skill. From this point of view, having assertive personal characteristics and social competence will positively affect his or her adjustment to university. Being confident, having positive thinking power and having an identity that can express himself or herself are evidences of assertive characteristics, and these characteristics contribute to their academic adjustment (Sülek-Şanl, 2015). If the student is able to adjust to the new environment he or she has been entering academically and socially, he or she will adjust to university life and will be more advantageous in terms of course achievement. In addition to strengthening his or her ties to the university, this will be important in terms of self-development and taking opportunities (Tinto, 1993). Pascarella and Terenzini (1980) found that a significant proportion of those who could not adjust to university environment had dropped out of university. It is very important for the individual to be assertive in order to avoid this kind of situation. Similarly, in his study, Amanvermez (2015) found that assertiveness was an important predictor of adjustment to university environment and academic adjustment. In addition, the positive academic perceptions of the assertive university students were higher (Lee \& Çiftçi, 2013).

The regression analysis performed to predict the first-year university students' social adjustment levels revealed that assertiveness was a significant predictor of social adjustment. Just like ensuring social adjustment is inevitable in every aspect of life, it is also a facilitating factor in university life. Social adjustment involves the student making 
himself or herself a part of the social environment (Baker \& Siryk, 1984). Social adjustment is also the ability of the individual to adjust to other people and to introduce himself or herself in his or her own group in a unique way (Yavuzer, 2007). These statements also refer to the concept of social skill. Assertive individuals are individuals who have high problem-solving skills (Özbulak et al., 2011), high self-esteem (Uğurluoğlu, 1996), and social skills (Bishop, 2013) and who can deal better with stress (Görüş, 1999). Students with low assertiveness levels might have difficulty in social adjustment since they experience more anxiety and difficulty in their social relationships (Amanvermez, 2015). It is inevitable for individuals who are socially weak and who are not self-confident to experience social maladjustment in the university. There is also a significant relationship between social skills and school compliance (Kabasakal \& Çelik, 2010). Tinto (2006) emphasized that students can adjust by establishing new and meaningful social support systems during their transition to university. The place of assertiveness in creating social support is tremendous. Entering a different environment can affect individuals' general adjustment and social adjustment. Social adjustment problems that arise during this period due to loneliness and change can be solved through healthy communication (Ceyhan, 2006). Brooks and Dubois (1995) emphasized that outwardness (assertiveness) was correlated positively with university life and positively related to general adjustment. Thus, individuals can adjust quickly. It is inevitable for individuals with these skills to be more adjusted and to have high social adjustment. Furthermore, assertiveness has positive correlation with social adjustment (Simarmata \& Rahayu, 2018) and Rini, Bahri and Zuliani (2016), similarly, found a significant relationship between assertive behavior and social adjustment.

The regression analysis performed to predict the first-year university students' personal adjustment levels revealed that assertiveness was a significant predictor of personal adjustment. Personal adaptation involves concepts such as self-esteem and selfworthiness (Aladağ, Kağnic1, Tuna \& Tezer, 2003). Students with high assertiveness levels also have high problem-solving skills, social competence expectations and selfesteem (Biçer, 2009; Güven, 2010). Assertiveness is associated with psychological wellbeing and self-esteem (Sarkova, et al., 2013). Assertive individuals can solve problems better, can socially express themselves and have high self-esteem. This can be attributed to the fact that they are successful at adjustment. Moon (2009) stated that individuals with a high assertiveness level are good at personal adjustment. Assertiveness is to be extroverted. Extraversion, one of the determinants of personal adjustment, indicates adjustment to life at a better level (Schnuck \& Handal, 2011). Assertiveness contributes to personal adjustment when faced with new situations by ensuring that the individual is successful in his or her social life and acquires more effective communication skills (Voltan Acar, Arıcıoğlu, Gültekin \& Gençtanırım, 2008).

The regression analysis performed to predict the first-year university students' levels of relationships with the opposite sex showed that assertiveness was a significant predictor of relationships with the opposite sex. Relationship with the opposite sex includes continuing the relationship with the person individuals date, entering into an emotional relationship, satisfaction with sexuality and feeling fear. In the light of the study findings, it can be said that assertiveness is an important variable for the relationship 
with the opposite sex variable in first-year university students. Since relationship with the opposite sex includes a second individual, it cannot be considered independent of the social adjustment concept. An assertive individual is effective in his or her interpersonal relationships during and after the university (Ateş \& Çelik, 2018). An assertive individual makes eye contact during communication, uses appropriate gestures with his or her comfortable but upright posture, establishes honest and open communication (Richardson, 2000) and exhibits socially appropriate behaviors (Waters, 1997). Individuals who feel lonely and who are inadequate in their interpersonal relationships will have difficulties in their relationships with the opposite sex and will have adjustment problems due to the lack of social relationships (Özkan \& Yllmaz, 2010). Individuals with relational-interdependent self-construal were better at establishing relationships (Cross, Morris and Gore, 2002). The assertive individuals also have these characteristics of self and the relationship with the opposite sex is also good. Thus, having assertive characteristics is very effective in adjustment to university and adjustment to the opposite sex.

The regression analysis performed to predict the first-year university students' emotional adjustment levels revealed that assertiveness was a significant predictor of emotional adjustment. Emotional adjustment refers to the student being psychologically and physically well, and being satisfied for being a student at the university he or she goes to (Baker \& Siryk, 1984). It is also a state of physiological and mental well-being including anxiety, depression and somatic symptoms (Cohorn \& Giuliano, 1999). The study results showed that assertiveness was associated with psychological adjustment (Uz-baş, 2017). Similarly, the study findings of Ateş and Çelik (2018) and Sarkova, et al. (2013) revealed that assertiveness significantly predicted psychological well-being and that there was a strong relationship between assertiveness and emotional adjustment. According to Olinger, Shaw and Kuiper (1987), individuals with low reliability experience have more problems in their relationships. This situation is closely related to the emotional adjustment of students. If the person is mentally and physically very satisfied, his or her emotional adjustment is also high. Assertiveness skill helps the individual to develop other social skills, to reach what they are interested in more quickly, to use opportunities and to adjust more emotionally to the environment.

The results of this present study should be evaluated within the framework of their limitations. The study results are based on the personal opinions of the individuals participating in the study group and can only be interpreted in terms of young people with similar socio-cultural structure and developmental stage. The study group consisted of young people studying at the faculty of education of a university in Central Anatolia. Conducting the study only in one city and only with students attending the faculty of education are limitations of the study. Therefore, this study may be repeated with different sample groups. It is also important to examine other variables affecting adjustment to university. In order to avoid adjustment problems, infrastructure meeting the basic needs of the students should be prepared. A training on assertiveness including activities promoting emotional, personal-social, academic and opposite sex adjustment can be provided to individuals who have adjustment problems. In addition, it is vital to conduct new studies since there are very few studies explaining the relationship between 
assertiveness and adjustment to university life. The results of this study can encourage university administrations to give importance to orientation studies in order to accelerate and facilitate the adjustment process.

\section{REFERENCES}

Akdağ, M. (2011). SPSS'de istatistiksel analizler. Ders notları, Malatya. Retrieved from: http://inonu.edu.tr/tr/mustafa.akdag/1237/menü.

Akeren, I. (2017). Examination of social support and assertiveness with need for psychological hep in university students (Unpublished master thesis). Atatürk University, Erzurum, Turkey.

Akgül, A. \& Çevik, O. (2003). Istatistiksel analiz teknikleri SPSS'te işletme yönetimi uygulamalart. Ankara: Emek Ofset.

Aktaş, Y. (1997). Üniversite öğrencilerinin uyum düzeylerinin incelenmesi: Uzunlamasına bir çalışma. HÜ Ĕ̈itim Fakültesi Dergisi, 13, 107-110.

Aladağ, M., Kağnıcı, D. Y., Tuna, M. E., \& Tezer, E. (2003). University life scale (ULS): A study on scale construction and construct validity. Turkish Psychological Counseling and Guidance Journal, 2(20), 41-47.

Alberti, R., \& Emmons, M. (2002). Kendinize yatırım yapın, atılganlık (Çev. Katlan, S.), Ankara: HYB.

Amanvermez, Y. (2015). Predicting freshmen students' university adjustment according to assertiveness and learned resourcefulness levels (Unpublished master thesis). Ege University, Izmir, Turkey.

Ateş, B. (2013). Investigate the assertiveness scores of the 5th grade students according to the several variables. Erzincan University Journal of Education Faculty, 15(1),50-66.

Ateş, B., \& Çelik, O. (2018). Perceived social competence and assertiveness as a predictor of psychological well-being in pre-service teachers. Erzincan University Journal of Education Faculty, 20(2), 444-460. doi:10.17556/erziefd.403476.

Baker, R. W. ve Siryk, B. (1984). Measuring adjustment to college. Journal of Counseling Psychology, 31(2), 179-189. doi:10.1037/0022-0167.31.2.179.

Baker, R. W., \& Schultz, K. L. (1992). Experiential counterparts of test-indicated disillusionment during freshman adjustment to college. NACADA Journal, 12(2), 13-22. doi:10.12930/0271-9517-12.2.13.

Baker, R. W., McNeil, O. V., \& Siryk, B. (1985). Expectation and reality in freshman adjustment to college. J. of Counseling Psyc., 32(1), 94 doi:10.1037/0022-0167.32.1.94.

Biçer, E. (2009). Investigation of assertiveness and social self-efficacy expectation levels of adolescents who have single parents and parents in terms of some demographic variables (Unpublished master thesis). Çukurova University, Adana, TUR.

Bishop, S. (2013). Develop your assertiveness. USA: Kogan Page.

Brady-Amoon, P., \& Fuertes, J. N. (2011). Self-efficacy, self-rated abilities, adjustment, and academic performance. Journal of Counseling \& Development, 89(4), 431-438. doi:10.1002/j.1556-6676.2011.tb02840.x. 
Büküşoğlu, N., \& Bayturan, A. F. (2005). The role of leisure time activities on the concept related to the psycho-social development of the youth. Ege Journal of Medicine, 44(3), 173-177.

Bülbül, T., \& Acar Güvendir, M. (2014). A research study on freshman students' higher education integration levels. J.ournal of Educational Sciences Research, 4(1), 397-418. doi:10.12973/jesr.2014.41.21.

Ceyhan, A. A. (2006). An investigations of adjustment levels of Turkish university students with respect to perceived communications skill levels. Social Behavior and Personality, 34(4), 367-380. doi:10.2224/sbp.2006.34.4.367

Ceyhan, A. A. (2011). University students' problematic internet use and communication skills according to the internet use purposes. Educ. Sci.: Theory \& Prac., 11(1), 59-77.

Credé, M., \& Niehorster, S. (2012). Adjustment to college as measured by the student adaptation to college questionnaire: A quantitative review of its structure and relationships with correlates and consequences. Educational Psychology Review, 24(1), 133-165. doi:10.1007/s10648-011-9184-5.

Cross, S. E., Morris, M. L., ve Gore, J. S. (2002). Thinking about oneself and others: the relational-interdependent self-construal and social cognition. Journal of Personality and Social Psychology, 82(3), 399-418.

Çokluk, Ö., Şekercioğlu, G. \& Büyüköztürk, Ş. (2010). Sosyal bilimler için çok değişkenli istatistik SPSS ve LISREL uygulamaları. Ankara: Pegem.

Erdoğan, S., Şanlı, H. S., \& Bekir, H. Ş. (2005). Adaptation status of Gazi university faculty of education students to university life. Kastamonu Educ. Journal, 479- 496.

Gökkaya, M. (2016) Evaluation of the relationship between social anxiety, depression and parental attitude, and perfectionism tendencies and adjustment to university on a group of university students (Unpublished master thesis) Işık University, Istanbul. TUR. Güdek, K., (2014) Terapötik iletişim ve sosyal çalı̧̧ma. İstanbul: Nobel Tip.

Gündoğdu R. (2012). Effect of the creative drama-based assertiveness program on the assertiveness skill of psychological counsellor candidates. Educational Sciences: Theory and Practice, 12(2), 677-693.

Güven, M. (2010). An analysis of the vocational education undergraduate students' levels of assertiveness and problem-solving skills. Procedia Social and Behavioral Sciences, 2, 2064-2070. doi: 10.1016/j.sbspro.2010.03.282.

Huck, S.W., (2008). Reading statistics and research. Boston - New York: Pearson Educational Inc., Allyn and Bacon.

İkiz, E., Asıc1, E., Savc1, M., Yörük, C. (2015). Relations between problematic internet usage and adaptation to college life. Bartin University Journal of Faculty of Education, 4(1), 34-50. doi:10.14686/BUEFAD.2015111013.

Kabasakal, Z., \& Çelik, N. (2010). Sosyal beceri eğitiminin ilköğretim öğrencilerinin sosyal uyum düzeylerine etkisi. Illköğretim Online, 9(1), 203-212. Retrieved from http://dergipark.ulakbim.gov.tr/ilkonline/article/view/5000038099/5000124688. 
Kalaycı, Ş. (Ed.) (2005). SPSS uygulamalı çok değişkenli istatistik teknikleri. Ankara: Asil.

Karahan, F., Sardoğan, M. E., Özkamalı, E., \& Dicle, A. N. (2005). An investigation on academic, social and individual adjustment to university. Cukurova University Faculty of Education Journal, 2(30), 63-72.

Karahan, T. F. (2005) Bir iletişim ve çatışma çözme beceri eğitimi programının üniversite öğrencilerinin güvengenlik düzeylerine etkisi. Journal of Uludag University Faculty of Education, 18(2), 217-230.

Köseler, A. (2006). Communication anxiety among the high school students (Unpublished master thesis). Çanakkale On Sekiz Mart University, Çanakkale, Turkey.

Lee, J. Y., \& Çiftçi, A. (2013). Asian international students' socio-cultural adaptation: Influence of multicultural personality, assertiveness, academic self-efficacy, and social support. International Journal of Intercultural Relations, 38, 97-105.

Memduhoğlu, H. B., \& Tanhan, F. (2013). Study of organizational factors scale's validity and reliability affecting university students' academic achievements. $Y Y U$ Journal of Education Faculty, 10, 106-124.

Mercan, Ç. S., \& Yıldız, S. A. (2011). Eğitim fakültesi birinci sınıf öğrencilerinin üniversiteye uyum düzeylerinin farklı değişkenler açısından incelenmesi. HAYEF Journal of Education, 8(2), 135-154.

Moon, J. (2009). Achieving success through academic assertiveness: Real life strategies for today's higher education students. New York: Routledge.

Morganett, R. S. (2005). Ergenler için grupla psikolojik danışma uygulamaları. (Çev. S. Güçray, A. Kaya ve M. Saçkes). Ankara: Pegem Akademi.

Olinger, L. J., Shaw, B. F., ve Kuiper, N. (1987). Nonassertiveness, dysfunctional attitudes, and mild levels of depression. Canadian Journal of Behavioural Science/Revue canadienne des sciences du comportement, 19(1), 40-49.

Orhunbilge, N. (2000). Örnekleme yöntemleri ve hipotez testleri. İstanbul: Avc1ol.

Özkan, S., \& Y1lmaz, E. (2010). Adaptation status of university students to university life (Bandırma example). Fırat Sağllk Hizmetleri Dergisi, 5(13), 151-173.

Öztemel, K. (2010). Investigation of adjustment levels of technical education faculty students. Journal of Polytechnic, 13(4), 319-325. doi: 10.2339/2010.13.4, 319-325.

Pamuk, U. E. (2013). The relationship among secondary school students' assertiveness level and peer pressure (Unpublished master thesis). Yeditepe University, Istanbul, TR.

Rahat, E. (2014). Benlik kurgusu, sosyal destek, başa çıkma stilleri ve yılmazlığın üniversite yaşamina иуuти (Unpublished master thesis) Gaziosmanpaşa University, Tokat, Turkey.

Richardson, S. S. (2000). The effects of an assertiveness training intervention on clients' level of assertiveness, locus of control and ways of coping with se-rious illness (Unpublished doctoral dissertation). Louisiana State University, Louisiana. 
Sarkova, M., Bacikova-Sleskova, M., Orosova, O., Madarasova Geckova, A., Katreniakova, Z., Klein, D., \& van Dijk, J. P., (2013). Associations between assertiveness, psychological well-being, and self-esteem in adolescents. Journal of Applied Social Psychology, 43(1), 147-154. doi: 10.1111/j.1559-1816.2012.00988.x.

Sevinç, S. (2010). Mersin Üniversitesi birinci sınıf öğrencilerinin kişisel ve kurumsal uyumların olumsuz etkileyen faktörlerin incelenmesi (Unpublished master thesis). Mersin University, Mersin, Turkey.

Schnuck, J., ve Handal, P. J. (2011). Adjustment of college freshmen as predicted by both perceived parenting style and the five-factor model of personality. Personality and Adjustment Psychology, 2(4), 275-282.

Sülek-Şanl1, G., (2015). The relation between university students' psychosocial development level and their adaptation to the university (Unpublished master thesis). Akdeniz University, Antalya, Turkey.

Sürücü, M., \& Bacanll, F. (2010). An examination of university adjustment according to psychological hardiness and demographic variables. GU Journal of Gazi Educational Faculty, 30(2), 375-396.

Şimşek, H. (2013). University students' tendencies toward and reasons behind dropout. Journal of Theoretical Educational Science, 6(2), 242-271.

Tinto, V. (1993). Leaving college: Rethinking the causes and cures of student attrition. Chicago: The University of Chicago.

Uz-Baş, A. (2017). Kişiler arası ilişkiler ve iletişimde güvengenlik. In A. Kaya (Eds.), Kişilerarasi ilişkiler ve etkili iletişim (pp. 174-194). Ankara: Pegem Akademi.

Voltan-Acar, N. (2004). Ne kadar farkındayım-gestalt terapi. Ankara: Babil.

Voltan-Acar, N. \& Öğretmen, T. (2007). Developing processes of assertiveness scale Turkish Psychological Counseling and Guidance Journal, 3(27), 67-78.

Voltan-Acar, N., Arıcıoğlu, A., Gültekin, F. \& Gençtanırım, D. (2008). Assertiveness level of university students. H. U. Journal of Education, 35, 342-350.

Waters, J. E. (1997). The effects of assertion training on high school females in English and Chemistry classes (Unpublished doctoral dissertation). The University of San Francisco, San Francisco.

Weiten, W., Hammer, E. Y., \& Dunn, D. S. (2012). Psychology and contemporary life: Human adjustment. United State: Wadsworth, Cengage Learning.

Yavuzer, H. (2002). Çocuk psikolojisi. İstanbul: Remzi.

Yilmaz S, Ekinci, M. (2001). The relotionship between the self-esteem and the assertiveness of the higher nursery college. Atatürk Üniversitesi Hemşirelik Yüksekokulu Dergisi. 4(2), 1-10.

Y1lmaz, E., Y1lmaz, E., \& Karaca, F. (2008). Examining the level of social support and loneliness of university students Genel Tip Dergisi, 18(2), 71-79. 